\title{
Barreto, Lima Recordações do escrivão Isaías Caminha, São Paulo: Penguin \& Companhia das Letras, 2010. 312 p.
}

\author{
Miguel Sanches Neto
}

Escrito em 1905 e publicado em 1909, Recordações do escrivão Isaías Caminha talvez seja a obra-prima de Lima Barreto (1881-1922). O romance acompanha o drama de ser mulato em uma sociedade convicta da superioridade ariana e que tentava esconder a mestiçagem que sempre nos caracterizou como país. É uma história vivida na pele pelo jovem escritor (tinha 24 anos) que não encontrava um lugar social condizente à sua genialidade.

Caminha, seu alter ego, é um moço talentoso, filho da relação arrependida entre um padre e sua empregada, que se destaca na escola da província e ousa querer continuar os estudos. Cheio de sonhos de realização pessoal, parte para o Rio de Janeiro com pouco dinheiro e uma carta de apresentação a um deputado. Da janela do trem, ele observa as árvores altas, sabendo-se igual a elas. Talvez, por isso, tenta ignorar o conselho quase calado de sua mãe: "Vai, meu filho - disse-me ela afinal! - Adeus!... E não te mostres muito, porque nós...” (p.78).

A sua pretensão de ser doutor despertará o desprezo de todos: do dono do hotel em que inicialmente fica hospedado, e que acusará o único mulato de um furto, ao delegado que o toma por malandro; do deputado que se irrita com essa mania [das classes subalternas] de estudo; aos amigos jornalistas com quem convive na condição de contínuo. Sempre cospem na sua cara a palavra "mulatinho".

Sem conseguir se matricular em nenhum curso superior, Caminha compreende a mecânica social do país, movida pelos títulos de doutor, pelo prestígio dos sobrenomes, pelos interesses econômicos e pelo exibicionismo de uma cultura de fachada. Trabalhando no jornal mais popular do Rio, ele conhece os bastidores das nomeadas, produzidas publicitariamente sem o menor pudor.

Lima Barreto desmascara assim os figurões do momento, fazendo a caricatura de Coelho Neto, João do Rio e outros. Mais do que um desejo de vingança, estes retratos defendem um conceito de língua e de cultura. Avesso aos preciosismos e aos penduricalhos, ele nega a linguagem de figurino ao zombar de seus cultores mais boçais. Como antídoto, Lima Barreto escreve um romance em uma língua viva, próxima do povo, iniciando a modernização de nosso idioma literário. 
No romance, Caminha se torna acidentalmente repórter, fazendo-se íntimo da alta boemia. Mas, num passeio rural com o chefe e uma meretriz italiana, esta observa que a paisagem local é feia porque carente de grandes árvores. Caminha, que se identifica a este mato rasteiro por não ter conseguido forças para erguer-se contra o meio, ultrapassando a condição marginal de sua mãe, decide voltar para a roça como escrivão: "A má vontade geral, a excomunhão dos outros tinham-me amedrontado” (p.301).

Seu último ato de orgulho é narrar a própria vida, negando a tese determinista de que negros e mulatos não se destacam por vícios próprios da raça. É a má vontade geral e a excomunhão que os destroem.

Silenciado quando de sua publicação, este romance de estreia antevia o destino do próprio autor. Obrigado a deixar a faculdade para sustentar a família, Lima Barreto passa a viver da colaboração de jornais e de um pequeno emprego público. Rende-se ao alcoolismo, tendo ido parar três vezes no hospício. Sua candidatura à Academia Brasileira de Letras é sistematicamente recusada. E ele morre, solteiro e órfão de afetos, aos 41 anos, justamente em 1922, quando começaria uma valorização de nossa pátria mestiça, da qual ele é hoje o maior ícone. 